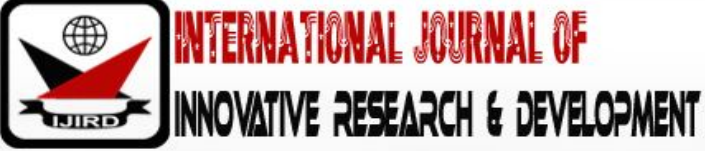

ISSN 2278 - 0211 (Online)

\section{Impact of System Security on the Successful Implementation of E-Procurement: A Survey of the Multinational Tea Companies in Kericho County, Kenya}

\author{
Evalyne Chepkemoi \\ Lecturer, Department of Business Management, Bomet University College, Kenya
}

\begin{abstract}
:
Security of an electronic system in has been one of the considerations in implementing any organization. This is one of the impending challenges in any organization to ensure information of retention. The electronic procurement is one of the current trend in many multinational corporation. The paper's objective assesses the impact of security on the successful implementation of e-procurement systems by multinational tea companies in Kericho County. Cross-sectional survey research was conducted targeting three multination companies with a sample of 63 respondents. Primary data using questionnaire were used were both descriptive and inferential statistics were used. According to data findings; the independent variable system security was found to have correlation coefficients of 0.409 with the implementation of e-procurement among the multinational tea companies involved in the study. Conclusions are that the lack of system security was found to be key impediment to the implementation of e-procurement. Recommendations are that full adoption and implementation is a necessity that can only be achieved through a collaborative effort among the key players specific field. It is necessary that the involved tea firms should look at a means of working together as a team and build systems that will allow easier eprocurement functionality.
\end{abstract}

Keywords: System security, e-procurement, Bomet, Kenya

\section{Introduction}

E-Procurement is the B2B purchase and sale of supplies and services through a network. It is one of the activities that require the use of the internet and ICT in order to maximize on its efficiency, effectiveness and productivity of its operation.

It connects business houses and business processes with the suppliers by managing all the correspondence between them.

A study by Croom and Brandon (2005), identified five forms of electronic procurement structures as exchange, public web, market place, extranet and company hub. The uses internet which is public web place allows the supplier and the buyer can access information through the search engines. Based on the listed pricing it is easy to place which make it easy to order and payment can be done on receiving order. The orders can be place through telephone, e-mail or on-line portals. Exchange is used to mean trading site where it allows both B2B and B2C access free markets, services and deals through web platform an example of eBay. This sites enable bidding of contracts between buyer and seller for both private and commercial through e-commerce. Extranet links the buyer and seller through secure internet link. It effected method of passing information between the two trading partners (Croom \& Brandon, 2005)

\subsection{Multinational Tea Companies}

E-Procurement is widely used by multinational tea companies to transfer viable information and financial transaction especially in internal trade to ease transactions. Kenya is forth worldwide and the leading in Africa in tea production. It is also leading income earner and source of revenue in Kenya. Black Ceylon tea is the largest imported and produced in Kenya by small as well as plantation management by multination companies. There are three multinational tea companies in Kericho County, Kenya, with Unilever tea Kenya ltd (UTKL) owning a total of 8,250 hectares under tea while James Finlay's is the second with 5,554 hectares of tea. KHRC (2008) Williamson tea is the next which is a family owned business.

\subsection{Research Hypothesis}

The null hypothesis investigates if; there is no significant effect of system security on the successful implementation of e-procurement. 


\section{Literature Review}

\subsection{Overview of System Security}

The past research studies have identified challenges faced in the implementation of e-procurement which included technological integration and security issues. Barcelo (1999)argued that internet is just a mean of communication but not a strategy in e-procurement. The challenge of internet is based on technical issues change in technology has disruptive effect on the organization using this systems. (Anne, Åsa \& Esmail, 2008).

According to Bell (2001), in 1999, 59\% of companies that suggested that the challenge in adapting e-procurement is security issues. This is brought about people who are looking for a way of getting cheap money through bridging the security. The tradition threats are associated the use of Trojans, worms and viruses that can jeopardize information integrity. This set of security threat affect the information, application, mails among many other e-procurement related system (Shwan, 2006).

Also according to Shwan (2006), information should be protected with in the computer system from manipulation, disclosure, unauthorized access and or theft of information both physically or electronically. This can be enhance through use of biometric technology, passwords, digital signature and encryption approach (Hall, 2006). Majority of these internet based security threat affect the implementation of e-procurements this include software backdoors, denial of service, spoofing and use of eavesdropping sniffer programs (Dillard, 2001)

On privacy and authentication issues involve e-commerce parties should be concerned how to beef up security. It is noted that about $90 \%$ of web sites fail to comply with privacy policies and principles. This makes contribute to losses of about 2.8 billion US dollars in a year in US(Escalante, 2003). Lin et al (2010) found that some health care practitioners related challenges of e-procurement include security and data recovery. Backups and alternative e-procurement system are some of the important concerns to alleviate the challenges of disaster recovery and security of data as contingency plan.

According to Saeed and Leith (2003) result it indicated security risk comes from an authorized access to transmission, storage and access of e-procurement system. This is as result of unauthorized access to trading platform and failure to protect data transmission. Kheng and Al-Hawandeh (2002) found that some of the issues affecting Singapore firms were security and the data privacy in transaction. Information location in search engine and lack of standardized system has also contributed to the adoption of e-procurement.

Escalante (2003) argued that despite insecurity there is growth of use of online platforms in transaction and has raised issues of legality of online transaction. This is based on online signatures that can mislead or affect transaction. Winn (2001) suggested that though digital signature is legal but there is still issues of security technology functions.

\subsection{Insecurity in E-Transactions}

Insecurity of e-transaction include worms, virus and theft among other factors that can affect the transmission of transaction from sender to recipient. These are done by hackers, employees, partners or clients affecting the integrity, confidentiality or security of transaction data. It is then very important to ensure data is secured from external threat since companies can lose a lot of money or viable information (Seng \& Hwee, 2003).

\section{Methodology}

\subsection{Data Design and Collection}

Descriptive cross-section design was used to collect both primary data and secondary data. A sample of 63 responded were obtained from three multinational tea companies Unilever, Finlays and Williamson limited companies.

\subsection{Model Specification}

The data deployed both descriptive and inferential statistics with assistance of SPSS software tool. Descriptive were presented in frequency tables and inferential using ANOVA analysis.

\section{Findings and Discussion}

\subsection{System Security}

The findings on system security were provided by descriptive statistics and inferential statistics respectively.

\subsubsection{Type of E-Procurement Used}

The data on models used in e-procurement technology were in defined on the basis of online orders, e-payments, e-catalogues, e-tendering and electronic data interchange. 


\begin{tabular}{|c|c|c|}
\hline E-procurement Technology & Count & Percent \\
\hline Online ordering & 31 & $49.2 \%$ \\
\hline Electronic payment & 37 & $58.7 \%$ \\
\hline Electronic catalogues & 39 & $61.9 \%$ \\
\hline E tendering & 24 & $38.1 \%$ \\
\hline Electronic data interchange & 59 & $93.7 \%$ \\
\hline
\end{tabular}

Table 1: Models of E-Procurement System Used

Source: Survey Data (2014)

The survey indicated majority the model of the system that is highly used were electronic data interchange 59(93.7\%). They were followed by 39(61.9\%) e-catalogue, 37(58.7\%) e-payment, 31(49.2\%) online ordering and $14(38.1 \%)$ e-tendering respectively. Hence security is crucial entity in sending, transmission and reception of information.

\subsubsection{Existence of Security Challenges}

According to findings the existence of security threat and challenge were assessed and represented in Table 2 .

\begin{tabular}{|c|c|c|}
\hline Security as a Challenge & Count & Percent \\
\hline Yes & 49 & $77.8 \%$ \\
\hline No & 14 & $22.2 \%$ \\
\hline Total & 63 & $100 \%$ \\
\hline
\end{tabular}

Table 2: Security as a Challenge

Source: Survey data (2014)

The finding indicates that significant number of respondent acknowledge that there were challenges in security $49(77.8 \%)$ and few were of the contrary opinion $14(22.2 \%)$.

\subsubsection{Level to Which System Security is a Challenge}

The extent to which the system security challenge influence system security were evaluated are presented in Table 2 Below.

\begin{tabular}{|c|c|c|c|c|c|}
\hline Security Element & Very High & High & Average & Low & Very Low \\
\hline Data loss & $13(20.6 \%)$ & $35(55.6 \%)$ & $10(15.8 \%)$ & $5(7.9 \%)$ & $0(0 \%)$ \\
\hline Unauthorized Access & $46(73.0 \%)$ & $10(15.9 \%)$ & $7(11.1 \%)$ & $(0.0 \%)$ & $0(0 \%)$ \\
\hline Impersonation & $4(6.3 \%)$ & $15(23.8 \%)$ & $41(65.1 \%)$ & $3(4.7 \%)$ & $0(0 \%)$ \\
\hline Information Leakage & $19(30.1 \%)$ & $37(58.7 \%)$ & $6(9.5 \%)$ & $1(1.6 \%)$ & $0(0 \%)$ \\
\hline Back up Recovery & $23(36.5 \%)$ & $31(49.2 \%)$ & $9(14.3 \%)$ & $0(0.0 \%)$ & $0(0 \%)$ \\
\hline Hacking & $6(9.5 \%)$ & $18(28.6 \%)$ & $39(61.9 \%)$ & $0(0.0 \%)$ & $0(0 \%)$ \\
\hline
\end{tabular}

Table 3: Extent of Security Challenges

Source: Survey Data (2014)

The findings in Table 3 indicated the data loss was one of the factor that affect system security to high extend on the implementation e-procurement (mean of 3.886). The security bridge through unauthorized access was significant in affecting implementation of e-procurement (mean of 4.619). Impersonation is also considered to be averagely affecting the implementation of e-procurement (mean of 3.314). Information leakage very highly affected the implementation of eprocurement (mean of 4.170). Back up recovery has affected positively to greater extend to the implementation of eprocurement (mean of 4.222). Hacking has been seen to be highly affecting implementation process of e-procurement (mean of 3.476). Dillard (2001) identified online threats as factors affecting the security which was positively identified in the research. Another study by Saeed and Leith (2003) concurred with the findings on the security bridge as result of unauthorized persons.

\subsection{ANOVA Analysis}

Analysis of variance conducted on the success of e-procurement was given by table 4 below.

\begin{tabular}{|c|c|c|c|c|c|}
\hline & Sum of Squares & df & Mean Square & F & Sig. \\
\hline Between Groups & 10.451 & 3 & 3.484 & 7.039 & .000 \\
\hline Within Groups & 29.200 & 59 & .495 & & \\
\hline Total & 39.651 & 62 & & & \\
\hline
\end{tabular}

Table 4: One Way ANOVA with SPSS 21.0

Source: Survey Data (2014)

There was significant effect of security system on the implementation of e-procurement $(F(3,59)=7.039, P<0.05)$. The implied that with proper system security the implementation can be significantly affected. 


\section{Conclusion and Recommendation}

\subsection{Conclusion}

Security of the systems in e-procurement is very critical aspect. Security threat as result of unauthorized is the highest threat, followed by information leakage, data loss, hacking and impersonation in that descending order. Back up is high recommended as one of measure. This elements negatively affects significantly on the implementation of eprocurement. It is important to evaluate data and information security in every organization.

\subsection{Recommendation}

System security is important besides that firm's embracing technology in replacement of manual process. This may results to poor implementation or financial losses as discussed in the literature. System developer and the organization's ICT manager then should consider security measures before developing, implementing or acquisition of any electronic system. Procurement also deal with asset as well as financial aspect of the organization which may lead to financial loss through the e-procurement system.

\section{References}

i. Anne, E., Åsa W. and Esmail S. (2008); Implementation of Public e-Procurement in Swedish Government Entities: A Proceeding of the International Multi-conference on Computer Science and Information Technology, pp. 315 319, ISBN 978-83-60810-22-4 ISSN 1896-7094, Sweden

ii. Bell, C. (2001). Exploiting emerging technology corruptly in the NSW public sector, availableathttp:/ / pandora.nla.gov.au/ pan/21452/ 20020110/ www.icac.nsw.gov.au/ pub/ public/ pub2_42cp.html, last visited May 2006.

iii. Croom, S. \& Brandon-Jones, A. (2005), "Key Issues in E-Procurement: Procurement Implementation and Operationin the Public Sector" A Journal of Public Procurement, Volume 5, Issue 3, 367-387

iv. Dillard C.T. (2001), e Commerce and Defense in Depth; SANS Institute, 2003; retrieved from www.iseca.org/mirrors/ sans.org/

v. Escalante, R.M. (2003), Socio-Legal Issues Affecting the Use of Digital Signatures for Secure E-commerce Transactions: A Caribbean Perspective, University of the West Indies, Trinidad

vi. Hall, M. (2006), IM Threats Steadily Evolving; e-Security Planet an article retrieved from www.esecurityplanet.com

vii. Kheng, C. Al-hawamdeh, S. (2002), The Adoption of Electronic Procurement in Singapore. Electronic Commerce Research, Vol. 2, 61-7

viii. KHRC (2008). A Comparative Study of the Tea Sector in Kenya: A Case Study of Large Scale Tea Estates. A Report by Kenya Human Rights Commission, Kenya,

ix. Seng, K.T. \& Hwee Y. W. (2003), Legal Challenges \& Strategies in E-Procurement in Construction; School of Civil \& Environmental Engineering Singapore

x. Shwan J. (2006), Wireless Communications and E-Commerce. Retrieved from www.searchwarp.com

xi. Shwan J. (2006), An article on Long champ Paris Commerce Security Challenges. Retrieved from www.searchwarp.com. 